\title{
Integrating the IncRNA and mRNA expression profiles of TLR4-primed mesenchymal stem cells in ankylosing spondylitis
}

Yuxi Li

Sun Yat-sen Memorial Hospital https://orcid.org/0000-0002-4470-7679

Ming Li

Sun Yat-sen Memorial Hospital

Jiajun Huang

Sun Yat-sen Memorial Hospital

Yuwei Liang

Sun Yat-sen Memorial Hospital

Junshen Huang

Sun Yat-sen Memorial Hospital

Xiangge Liu

Sun Yat-sen Memorial Hospital

Ziying Cheng

Sun Yat-sen Memorial Hospital

Shixin Lu

Sun Yat-sen Memorial Hospital

Ting Liu

Sun Yat-sen Memorial Hospital

Lin Huang ( $\square$ huangl5@mail.sysu.edu.cn )

Department of Orthopaedics, Sun Yat-sen Memorial Hospital, Sun Yat-sen University

\section{Research}

Keywords: Ankylosing spondylitis, Mesenchymal stem cells, Toll-like receptor 4, Long non-coding RNA, Immunoregulation

Posted Date: July 27th, 2020

DOI: https://doi.org/10.21203/rs.3.rs-45893/v1

License: (c) (i) This work is licensed under a Creative Commons Attribution 4.0 International License. Read Full License 


\section{Abstract \\ Background}

Our previous study found that the toll-like receptor 4 (TLR4) expression of ankylosing spondylitis (AS) patients was significantly different from that of healthy donors. The goals of this study were to explore the expression profiles and functional networks of IncRNAs and mRNAs in TLR4-primed mesenchymal stromal cells from AS patients (AS-MSCs) and to clarify the mechanisms by which TLR4-primed MSCs exert immunoregulatory effects in AS.

\section{Methods}

Firstly, the immunoregulatory effects of MSCs were determined after TLR4 activation. Then, the differentially expressed (DE) IncRNAs and mRNAs between the control group (AS-MSCs without stimulation) and experimental group (AS-MSCs stimulated with lipopolysaccharide) were identified through high-throughput sequencing followed by qRT-PCR confirmation. Finally, bioinformatic analyses were performed to identify the critical biological functions, signalling pathways and associated functional networks involved in the TLR4-primed immunoregulatory function of AS-MSCs.

\section{Results}

TLR4-primed AS-MSCs showed a strong ability to inhibit the proliferation of peripheral blood mononuclear cells (PBMCs) with $1 \mu \mathrm{g} / \mathrm{ml}$ LPS stimulation for 4 hours. A total of 147 DE IncRNAs and 698 DE mRNAs were identified between TLR4-primed AS-MSCs and unstimulated AS-MSCs. Significant fold changes in IncRNA and mRNA levels were confirmed by qRT-PCR. GO and KEGG analysis demonstrated that the DE mRNAs and IncRNAs were highly associated with the inflammatory response. Cis-regulation prediction revealed 9 novel IncRNAs while trans-regulation prediction revealed 15 IncRNAs, respectively.

\section{Conclusions}

Our research describes the IncRNA and mRNA expression profiles and functional networks in TLR4-primed AS-MSCs, which is supposed to enhance the understanding of the pathogenesis of AS-MSC immunoregulatory dysfunction.

\section{Background}

Ankylosing spondylitis (AS) is a chronic inflammatory rheumatic disease characterized by inflammatory back pain and asymmetrical peripheral arthritis [1]. Previous studies have shown that AS is closely related to immune dysfunction. However, the pathogenesis of AS is largely unknown. Mesenchymal stem cells (MSCs) are a group of self-renewing cells that have a significant immunomodulatory ability that allows them to regulate $\mathrm{T}$ cell proliferation and differentiation and inhibit dendritic cell (DC) maturation [2, 3]. According to recent studies, abnormal immunoregulation by MSCs can lead to several autoimmune diseases, such as immune thrombocytopenia and systemic lupus erythematosus (SLE) [4-6]. In our previous study, we found impairment in the immunoregulatory functions of MSCs from AS patients, which might play an important role in the pathogenesis of AS [7]. Furthermore, our clinical trial demonstrated that intravenous infusion of MSCs was a feasible, safe, and effective approach for the treatment of AS [8]. However, our understanding of the immunoregulatory function of MSCs is still in its infancy, and further characterization and identification of key factors regulating these properties are still needed.

Toll-like receptors (TLRs) have been demonstrated to play important roles in regulating the immunomodulatory properties of MSCs, but inconsistent results have been reported [9]. Liotta et al. found that ligation of TLR4 suppressed the inhibitory effects of human bone marrow (BM)-MSCs on T cell proliferation by downregulating Jagged-1 expression [10]. Waterman et al. demonstrated that MSCs could be primed towards a proinflammatory phenotype after TLR4 activation [11]. In contrast, Opitz et al. reported that TLR4 enhanced the immunosuppressive properties of human BM-MSCs by directly inducing indoleamine 2,3-dioxygenase 1 (ID01) [12]. Our previous study found that the expression of TLR4 in MSCs was downregulated in AS patients compared to healthy donors (HDs). The inhibitory effects of MSCs on CD $4^{+} \mathrm{T}$ cell proliferation in AS were enhanced by activation of TLR4. It has been suggested that TLR4 plays a significant role in regulating the immunomodulatory ability of MSCs in AS (AS-MSCs) [13]. However, the specific immunoregulatory mechanisms by which TLR4 controls MSC immunoregulation must be addressed.

Long non-coding RNAs (IncRNAs) are a type of non-protein-coding RNA greater than 200 nucleotides in length [14]. LncRNAs are important epigenetic regulators and thus participate in crucial roles in various cell biology behaviours [15]. Specifically, IncRNAs are widely involved in the regulation of immune system homeostasis $[16,17]$. However, the molecular mechanism by which IncRNAs participate in the immunoregulatory function of MSCs, particularly in AS, is still unclear.

The current study presents an integrative analysis of IncRNA-messenger RNA (mRNA) expression profiles and functional networks involved in the TLR4-primed immunoregulation of AS-MSCs. These results improve our understanding of the roles of IncRNAs in the immunoregulatory ability of 
AS-MSCs and could provide potential targets to improve the curative effect of MSCs on AS.

\section{Methods}

\section{AS-MSC isolation and cell culture}

MSCs were isolated from BM aspirates taken from AS patients who provided informed consent through density gradient centrifugation, as described in our previous study [18]. After density gradient centrifugation, MSCs were isolated through plastic adherence and grown at $37^{\circ} \mathrm{C}$ in an atmosphere of $5 \% \mathrm{CO} 2$ for one week. The MSCs were trypsinized when the cultures reached $80-90 \%$ confluence. MSCs in passages $3-5$ were used in subsequent experiments. MSCs were identified on the basis of immunological phenotypes and the triple-lineage differentiation capability, as previously described [18]. After identifying MSC immunophenotypic markers by flow cytometry, cells in passages three to five were used for subsequent experiments.

\section{Pre-stimulation of TLR4 on AS-MSCs}

To stimulate TLR4 on MSCs effectively, determining the proper stimulating concentration and treatment time of the TLR4 ligand (lipopolysaccharide, LPS) was necessary. For the time-based stimulation test, $1.0 \mu \mathrm{g} / \mathrm{ml}$ LPS (Sigma-Aldrich, USA) was added to the culture medium for different times $(0,2,4,8,12$ and 24 hours) before a mixed lymphocyte reaction (MLR) was performed. For the concentration-based stimulation test, different concentrations $(0,0.1,1$ and $10 \mu \mathrm{g} / \mathrm{ml})$ of LPS were added to cultured cells for the previously selected time. The best conditions for MSC TLR4 activation were evaluated by assessing the level of p38 phosphorylation by western blotting. After determining the best stimulation time and concentration of LPS, MSCs were pre-primed before co-culture with peripheral blood mononuclear cells (PBMCs) and gene analysis.

\section{Co-culture of AS-MSCs and PBMCs for PBMC proliferation analysis}

AS-MSCs were primed with $1 \mu \mathrm{g} / \mathrm{ml}$ LPS for 4 hours prior to co-culture with PBMCs to activate TLR4. PBMCs were harvested from blood samples taken from healthy donors using the Ficoll-Paque density gradient centrifugation method and then labelled with carboxyfluorescein diacetate succinimidyl ester (CFSE; BD Bioscience, USA). PBMCs were incubated with $5 \mu \mathrm{M}$ CFSE in phosphate-buffered saline (PBS) at $37^{\circ} \mathrm{C}$ for 5 mins. After the incubation, the staining reaction was terminated by washing the PBMCs with complete medium twice. For co-culture with AS-MSCs (effector cells), AS-MSCs at a density of $1 \times 10^{5}$ cells/well seeded in 6-well plates were stimulated with or without $1 \mu \mathrm{g} / \mathrm{ml}$ LPS for 4 hours and then subjected to Co-60 irradiation (30 Gy). CFSE-labelled PBMCs (responder cells) at a cell density of $1 \times 10^{6}$ were then added to the MSC cultures. The co-cultures were stimulated with human anti-CD3/CD28 monoclonal antibodies (mAbs; CD3: $200 \mathrm{ng} / \mathrm{ml}$; CD28: $1 \mu \mathrm{g} / \mathrm{ml}$, BD Bioscience, USA) for 5 days, after which the PBMCs were harvested and stained with an anti-CD4-FITC antibody (BD Bioscience, USA), and cell proliferation was evaluated using flow cytometry. A minimum of 10,000 live cell events gated in scatter plots were analysed for each sample.

\section{Library construction and high-throughput sequencing}

Three MSC samples from AS patients were separated into two subgroups: MSCs cultured without stimulation (control group, samples C1-C3) and MSCs stimulated with $1 \mu \mathrm{g} / \mathrm{ml}$ LPS for four hours to activate TLR4 specifically (experimental group, samples T1-T3). The total RNA concentration was quantified with a NanoDrop ND-2000 (Thermo Scientific), and RNA integrity was assessed using an Agilent Bioanalyzer 2100 (Agilent Technologies). Sample labelling, microarray hybridization and washing were performed based on the manufacturer's standard protocols. Briefly, total RNA was transcribed into double-stranded complementary DNA (cDNA), which was then synthesized into complementary RNA (cRNA) and labelled with Cyanine-3-CTP. The labelled cRNAs were hybridized onto the microarray. After washing, the arrays were scanned by an Agilent Scanner G2505C (Agilent Technologies). The Agilent Human IncRNA Microarray 2018 (4*180k, Design ID: 085630) was used in this experiment, and data analysis of the 6 samples was conducted by OE Biotechnology Co., Ltd. (Shanghai, China).

\section{Expression analysis}

Feature Extraction software (version 10.7.1.1, Agilent Technologies) was used to analyse array images to obtain raw data. GeneSpring (version 14.8, Agilent Technologies) was employed to complete the basic analysis with the raw data. First, the raw data were normalized with the quantile algorithm. The probes with at least 1 condition out of 2 conditions having flags in "Detected" were chosen for further data analysis. DE genes were then identified through fold change data as well as the $\mathrm{P}$ value calculated with a t-test. The threshold set for up- and downregulated genes was a fold change $\geq 2.0$ and a P value $\leq 0.05$. Afterwards, gene ontology (GO) and Kyoto Encyclopedia of Genes and Genomes (KEGG) analyses were 
applied to determine the roles of these differentially expressed (DE) mRNAs. Finally, hierarchical clustering was performed to display the distinguishable gene expression patterns among samples.

\section{qRT-PCR validation}

To validate the reliability of high-throughput RNA-seq and explore the expression trends of mRNAs and IncRNAs, we performed quantitative real-time PCR (qRT-PCR) for biological validation. Total RNA was isolated from AS-MSCs with or without LPS stimulation using TRIzol according to the manufacturer's protocol. cDNA was transcribed using a PrimeScript RT reagent kit (Takara, Otsu). qRT-PCR was then performed, and the data were analysed using the $2^{-\mathrm{DDCt}}$ method. The primer sequences used in the qRT-PCR assay are provided in Supplementary Table S1.

\section{Co-expression network of IncRNAs with mRNAs}

To further examine the potential roles of DE IncRNAs and mRNAs in TLR4-primed AS-MSCs, a DE IncRNA-mRNA co-expression network was constructed. First, the Pearson's correlation coefficient (PCC) between the expression levels of each DE IncRNA-DE mRNA pair in the TLR4-primed AS-MSCs and unstimulated AS-MSCs were calculated. Second, the DE IncRNA-DE mRNA pairs with an absolute PCC value $\geq 0.85$ and $P<0.05$ were defined as co-expressed DE IncRNA-DE mRNA pairs. The co-expressed DE IncRNA-DE mRNA pairs in which the expression level of the DE mRNA was positively correlated with the expression level of the DE IncRNA in TLR4-primed AS-MSCs were defined as positively co-expressed DE IncRNA-DE mRNA pairs. In contrast, negatively co-expressed DE IncRNA-DE mRNA pairs were defined as the expression level of the DE mRNA being negatively correlated with that of the DE IncRNA in TLR4-primed AS-MSCs. The co-expressed DE IncRNA-DE mRNA networks were visualized using Cytoscape 3.0 software.

\section{Cis- and trans-regulation predictions of DE IncRNAs}

It has been suggested that IncRNAs regulate gene expression through both cis- and trans-regulation. For cis-regulation prediction, we identified each paired IncRNA and mRNA by the following procedures: (1) the mRNA loci were within 100-kb windows upstream or downstream of the given IncRNA, and (2) the Pearson correlation of IncRNA-mRNA expression was significant $(P \leq 0.05)$. For trans-regulation prediction, we enriched the coexpressed mRNAs with DE IncRNAs that significantly overlapped with the host genes of transcription factors (TFs). Using the threshold $\mathrm{P}<0.05$, each IncRNA could be connected with one to more than a dozen TFs, and each pair of IncRNA-TF was the result of several gene enrichments based on the hypergeometric cumulative distribution function. Then, we constructed the IncRNA-TF-mRNA network using Cytoscape software.

\section{Statistical analysis}

Data are expressed as the mean \pm standard deviation (SD) and were analysed using the statistical software package SPSS16.0. Pearson correlation was used in IncRNA-mRNA co-expression analyses. A p value $<0.05$, fold enrichment $>2, a_{1} \log _{2} \mathrm{FC}>1$ were considered statistically significant.

\section{Results}

\section{The effect of TLR4 activation on AS-MSCs is time and dose dependent}

To investigate whether the activation of TLR4 in AS-MSCs can affect the immunoregulatory ability of these cells, AS-MSCs were pre-stimulated with LPS before being co-cultured with PBMCs. To determine the best stimulation time and concentration for the TLR4 ligand used, the level of p38 phosphorylation was examined by western blotting. MSCs were first exposed to LPS at a concentration of $1 \mu \mathrm{g} / \mathrm{ml}$ for the indicated times $(0,2,4,8$, 12 and 24 hours) and then treated with three different concentrations $(0,0.1,1$ and $10 \mu \mathrm{g} / \mathrm{ml})$ of stimuli for the previously selected time. The upregulation of the phospho-p38 level was highest at 4 hours with the LPS concentration of $1 \mu \mathrm{g} / \mathrm{ml}$ and declined thereafter (Fig. $1 \mathrm{~A}$ ).

\section{TLR4-primed AS-MSCs demonstrate an enhanced inhibitory effect on CD4 ${ }^{+} \mathrm{T}$ cell proliferation}

Previous reports have shown that co-culture of unprimed MSCs with PBMCs can inhibit PBMC proliferation and/or activation [19]. Thus, we sought to assess the potential influence of TLR4 activation on the immunoregulatory effect of MSCs derived from AS patients. To this end, MSC-PBMC coculturing was conducted with CFSE-labelled PBMCs (responder cells) co-cultured with unprimed or TLR4-primed MSCs (effector cells) for 5 days, after which time the proliferating responders were sorted by flow cytometry for CD4 positivity and then gated on CFSE expression. As shown in Fig. 
$1 \mathrm{C}, 72.8 \%$ of the $\mathrm{CD} 4^{+} \mathrm{T}$ cells underwent proliferation when cultured without MSCs, but this proportion was reduced to $46.3 \%$ when cultured with $\mathrm{AS}$ MSCs. Activation of TLR4 with $1 \mu \mathrm{g} / \mathrm{ml}$ LPS significantly enhanced the immunoregulatory effect of AS-MSCs, which reduced CD $4^{+} \mathrm{T}$ cell proliferation to $40.3 \%(p<0.05)$ (Fig. 1B). qRT-PCR results suggested that the expression of several cytokines and chemokines (TNF-a, CXCL-9, PDL1, IL-1 $\beta$, IL-6 and iNOS) was strengthened after stimulation with LPS (Fig. 1C).

\section{Identification of DE mRNAs and IncRNAs}

A total of 698 mRNAs were DE in TLR4-primed MSCs compared to unprimed MSCs from AS patients. Among these genes, 594 mRNAs were upregulated, and 104 mRNAs were downregulated. The DE mRNAs are depicted using a clustergram (Fig. 2A) and volcano plots (Fig. 2C). The 20 mRNAs with the largest fold changes are shown in Table 1. Several immunoregulatory cytokines and chemokines, such as CXCL10, CXCL11, ID01, CXCL8, CXCL1, CCL20, IL6 and SOD2, which are secreted by MSCs and play important roles in regulating immunocytes, were included in this list. A total of 147 IncRNAs, including 107 upregulated and 40 downregulated IncRNAs, were differentially expressed in TLR4-primed MSCs compared to unprimed MSCs from AS patients. The DE IncRNAs are depicted in a clustergram (Fig. 2B) and volcano plots (Fig. 2D). The 10 IncRNAs with the largest fold changes are shown in Table 2.

\section{Validation of DE mRNA and IncRNA expression levels}

To confirm the RNA-seq results, several important DE mRNAs and IncRNAs were assessed by qRT-PCR. We found that the expression of mRNAs (CXCL1, CXCL8, CXCL10, CXCL11 and CCL20) and IncRNAs (MIR3142HG, LOC105371619, LOC105374444, PACERR and LOC105375914) was significantly upregulated in TLR4-primed AS-MSCs compared to unstimulated AS-MSCs $(P<0.05)$ (Fig. 3A and 3B). All qRT-PCR results were consistent with the RNA-seq results, confirming the reliability of the sequencing data.

\section{GO and KEGG analyses}

We performed GO analysis of the DE mRNAs and IncRNAs. The top $10 \mathrm{GO}$ terms related to biological processes, cellular components and molecular functions are provided in Fig. 4A and supplementary table 1. In the biological process category, the top 5 GO terms associated with DE mRNAs were defence response to virus, type I interferon signalling pathway, interferon-gamma-mediated signalling pathway, inflammatory response and response to virus. In the molecular function category, the top $5 \mathrm{GO}$ terms associated with the DE mRNAs were chemokine activity, CXCR chemokine receptor binding, ubiquitin-protein transferase activity, double-stranded RNA binding and TF activity, and sequence-specific DNA binding. In the cellular component category, the top $5 \mathrm{GO}$ terms associated with the DE mRNAs were cytoplasm, cytosol, extracellular space, nucleus and extracellular region. KEGG analysis of the DE mRNAs determined that 75 pathways were significantly altered in TLR4-primed MSCs from AS patients. The top 30 affected pathways are shown in Fig. 4B. The top 10 pathways and DE mRNAs associated with these pathways are shown in supplementary table 2. The top pathways included the NOD-like receptor (NLR) signalling pathway, the TNF signalling pathway, the NF-kappa B signalling pathway, cytokine-cytokine receptor interaction, the IL-17 signalling pathway and the TLR signalling pathway, which contribute to the immunoregulatory function of AS-MSCs.

\section{Interaction and co-expression network analyses}

The interactions between proteins encoded by DE mRNAs are shown in Fig. 4C. OAS2, OAS3, OAS1, OASL, STAT1, IRF9, HLA-F, IRF1, IRF2 and HERC5 were identified as key genes that interact with many other DE mRNAs in this network. Based on the expression levels of DE IncRNAs and DE mRNAs, the PCC describing the co-expression association between 147 DE IncRNAs and 698 DE mRNAs was calculated. A total of 1,072 DE IncRNADE mRNA co-expression pairs were obtained with an absolute PCC value $\geq 0.85$ and $P<0.05$. Among these pairs, 706 IncRNA-mRNA pairs were identified as being positively co-expressed, whereas 366 IncRNA-mRNA pairs were found to be negatively co-expressed (Fig. 4D).

\section{Cis-regulation prediction of DE IncRNAs}

Cis-regulation, which regulates the transcription of nearby genes located on the same chromosome, is vital for gene expression. A total of 9 IncRNA transcripts and their predicted cis-regulated protein-coding genes were identified in the top 20 cis-regulated genes (Fig. 5A). POU6F2-AS2 was predicted to cis-regulate POU6F2, LOC107986962 was predicted to cis-regulate GRHL2, PIK3CD-AS1 and PIK3CD-AS2 were predicted to cis-regulate SLC26A4, LOC105376617 was predicted to cis-regulate C11orf91, GRM7-AS1 was predicted to cis-regulate ADAMTS9, GRM7-AS2 was predicted to 
cis-regulate ADAMTS10 and ADAMTS11, GRM7-AS3 was predicted to cis-regulate ADAMTS12 and ADAMTS13, and LOC102723716 was predicted to cis-regulate FGFR1. These networks may provide valuable clues about these IncRNAs and their nearby coding genes in the development of AS.

\section{Trans-regulation prediction of DE IncRNAs}

One of the important mechanisms by which IncRNAs function is by participating in particular pathways regulated by TFs. A top 500 IncRNA-TF network, which showed that 15 IncRNAs participate in pathways regulated by TFs, was constructed to provide key data for subsequent research (Fig. 5B). Then, we selected the abovementioned relationships among the IncRNAs and TFs and further introduced the target mRNAs to build the IncRNA-TF-mRNA network (Fig. 5C).

\section{Discussion}

In our present research, we utilized high-throughput sequencing followed by bioinformatic analysis to analyse the mRNA and IncRNA expression profiles and functional networks of TLR4-primed AS-MSCs. These findings were then confirmed by qRT-PCR. KEGG pathway analysis indicated that some key pathways, such as the NF-kappa B and TLR signalling pathways, might contribute to the immunoregulatory function of TLR4-primed ASMSCs. In addition, we obtained novel findings by bioinformatic analyses of DE transcripts, including identification of the most significantly altered GO categories, construction of a co-expression network for IncRNA function prediction, and cis- and trans-regulation predictions of IncRNAs. Our results provide a model that can be used to explore the roles of IncRNAs and mRNAs in the immunoregulatory mechanisms of TLR4-primed ASMSCs.

MSCs are one of the most important immunoregulatory cell types and regulate the functions of many immune cells, including T cells, B cells and DCs [20-22]. Abnormal immunoregulation by MSCs can lead to several autoimmune diseases [4]. Moreover, MSCs exert considerable therapeutic effects on several autoimmune diseases owing to their multilineage differentiation potential and highly immunoregulatory properties [23, 24]. In our previous study, we found that impairment in the immunoregulatory functions of MSCs played a key role in the pathogenesis of AS [7]. Additionally, our clinical trial study demonstrated that infusion of MSCs isolated from healthy individuals is a safe and efficient method for the treatment of AS [8].

Accumulating evidence suggests that TLR activation can modulate the immunoregulatory functions of MSCs [10-12]. In addition, emerging evidence further suggests a role for TLRs in the pathogenesis of spondyloarthropathies, including AS [25]. According to our previous study, the expression of TLR4 was downregulated in MSCs derived from AS patients, and compared with MSCs from healthy donors, TLR4-primed AS-MSCs possessed enhanced immunoregulatory effects limiting the proliferation of naive CD4 ${ }^{+} \mathrm{T}$ cells [26]. However, the precise mechanism underlying the enhanced immunoregulatory ability of TLR4-primed AS-MSCs remains unclear. Therefore, we measured the differential expression profiles of IncRNAs and mRNAs in AS-MSCs after TLR4 activation to identify the regulatory network of IncRNAs and mRNAs in these cells. The results showed that there were 698 DE mRNAs and 147 DE IncRNAs in TLR4-primed AS-MSCs compared with unstimulated cells. The top 5 mRNAs and IncRNAs, which may be involved in the regulatory dysfunction of AS-MSCs, were verified by qRT-PCR.

mRNA expression profiles reflect the biological behaviours and functions of cells. In this study, KEGG pathway analysis revealed that 75 signalling pathways exhibited significant differences between TLR4-primed AS-MSCs and unstimulated AS-MSCs. Among these pathways, the NLR signalling pathway, the TNF signalling pathway, the NF-kappa B signalling pathway, cytokine-cytokine receptor interaction and the TLR signalling pathway were prominent. Recent studies indicate that the activation of TLRs can activate NF-KB and MAPK signalling pathways to promote the secretion of pro-inflammatory cytokines, such as IL-6, IL-12, TNF-a and type I IFNs, which drive inflammation in AS [27]. Consistent with these findings, we found that the expression of TNF-a, IL-6 and IL1 $\beta$ in AS-MSCs was significantly increased after TLR4 activation, which supported the crucial roles for TLR4 in the NF-KB and MAPK signalling pathways identified by microarray analysis. In addition, as pathogen recognition receptors, both TLR and NLR activate pathways mediated through different adaptor proteins that are commonly found to activate NF-KB [28]. The NF-KB-mediated activation of MSCs leads to the secretion of TNF-a and other cytokines. Elevated pro-inflammatory cytokine levels are one of the main manifestations of AS, as confirmed by previous research. Our results further confirmed the significant role of TLR4 in the pathology of AS. The selected top DE mRNAs and IncRNAs included in the NF-KB pathway might be possible upstream targets of pathological inflammation in AS.

mRNA expression profiles are under the control of a series of epigenetic regulators, of which IncRNAs are an important component [15, 29]. In recent years, an increasing number of IncRNAs have been reported to perform key roles in the pathogenesis and development of AS. For example, IncRNAAK001085 expression was found to be downregulated in AS patients, which served as a potential diagnostic indicator; thus, this IncRNA is considered a potential suppressor of AS [30]. Our previous microarray study identified four IncRNAs (Inc-ZNF354A-1, Inc-LIN54-1, Inc-FRG2C-3 and Inc-USP50-2) that are involved in the abnormal osteogenic differentiation of AS-MSCs [31]. However, the immunoregulatory function of AS-MSCs regulated by IncRNAs has not been explored. Our research identifies the IncRNA expression profile in an inflammatory environment based on previous studies, which provides a possible way to further explore the regulatory function of IncRNAs in AS. To the best of our knowledge, this study is the first to use microarray analyses to examine the roles of IncRNAs in TLR4-primed AS-MSCs. 
In this study, several IncRNAs with the largest fold changes among DE IncRNAs were studied. For example, GBP1P1 is a IncRNA that acts as a prognostic biomarker for hepatocellular carcinoma [32]. MIR3142HG can regulate the inflammatory response following IL-1 $\beta$-mediated activation of human lung fibroblasts, which is a positive regulator of IL-8 and CCL2 release [33]. The inflammatory response regulation by MIR3142HG indicates that it may contribute to the enhanced immunoregulatory ability of TLR4-primed AS-MSCs and the immunoregulatory dysfunction seen in AS. Unfortunately, most of the DE IncRNAs, such as LOC101926887, LOC105378410, and LOC107984251, have not been studied yet. Further exploration is needed in the future.

Regulatory IncRNAs act in a cis and/or trans manner to influence or interact with nearby or distant genes [34]. In our study, 9 IncRNA transcripts were predicted to cis-regulate nearby protein-coding genes. In addition, we predicted the functions of trans-regulatory IncRNAs using TFs that regulate protein-coding gene expression. LncRNAs in the core IncRNA-TF-mRNA network were grouped into 8 categories of target mRNAs: SOD2, IFIT3, IFIT5, MICB, SP140L, GBP2, PTGS2 and HIVEP2. SOD2 is a component of antioxidant defence systems, which are crucial in defending cells against oxidative stress. SOD2-overexpressing BM-MSCs have an enhanced therapeutic effect on brain injury treatment in traumatic brain injury mice [35]. Following exposure to systemic sclerosis patient serum, MSCs enhance the expression of the SOD2 antioxidant gene to adapt to the oxidative environment and exert their therapeutic effect [36]. Exposure to LPS induces oxidative stress in AS-MSCs, so SOD in AS-MSCs may be crucial to defend cells against oxidative stress and to exert the immunoregulatory effects of the AS-MSCs. In addition, 15 IncRNAs were identified to function in a trans-regulation manner, but the underlying mechanisms of how "IncRNA-TF-target gene" networks affect TLR4-induced immunoregulation remain to be identified. We expect to integrate IncRNAs into the trans-regulatory network, which will help us to understand the transcriptional control of TFs. The above mentioned 24 DE IncRNA and nearby cis/trans target DE mRNA pairs identified in the present study provide novel information for understanding the biological functions of IncRNAs in AS-MSCs.

Our study has several limitations. First, RNA-seq is an important method to screen possible IncRNAs and mRNAs associated with specific diseases, but the results of big-data analyses may include false positives. Therefore, we performed qRT-PCR to further verify differential expression. Second, we predicted IncRNA functions only indirectly using bioinformatic analysis and validated several DE IncRNAs. Further functional studies on the mechanism are warranted to clarify the roles of IncRNAs.

\section{Conclusions}

Our research describes the IncRNA and mRNA expression profiles and functional networks in TLR4-primed AS-MSCs. These results provide insight into the pathogenesis of immunoregulatory dysfunction in AS-MSCs, which may help to elucidate possible molecular mechanisms and therapeutic targets in AS.

\section{Abbreviations}

AS: ankylosing spondylitis; MSCs: mesenchymal stromal cells; TLR4: toll-like receptor 4; DE: Differentially expressed; PBMCs: peripheral blood mononuclear cells; LncRNA: long non-coding RNA; mRNA: messenger RNA; DC: dendritic cell; SLE: systemic lupus erythematosus; BM: bone marrow; ID01: indoleamine 2,3-dioxygenase 1; HDs: healthy donors; qRT-PCR: quantitative real-time PCR; MLR: mixed lymphocyte reaction; CFSE: carboxyfluorescein diacetate succinimidyl ester; LPS: lipopolysaccharide; PCC: Pearson's correlation coefficient; NLR: NOD-like receptor.

\section{Declarations}

\section{Acknowledgements}

The authors thank American Journal Experts for providing English language editing of the manuscript.

\section{Authors' contributions}

Yuxi Li: Conception and design; Ming Li: Manuscript writing; Ting Liu: Data analysis and interpretation; Jiajun Huang, Yuwei Liang and Junshen Huang: Provision of study material or patients and cell culture; Xiangge Liu, Ziying Cheng and Shixin Lu: Collection and /or assembly of data; Lin Huang and Huiyong Shen: Conception and design, fund raising, management and adjustment.

\section{Funding}

This work was supported by the Guangdong Natural Science Foundation (Grant numbers: 2020A1515010371, 2017A030310554 and 2017A030313652). 
Not applicable.

\section{Ethics approval and consent to participate}

Sample collection was approved by the Ethics Committee of Sun Yat-sen Memorial Hospital, Sun Yat-Sen University.

\section{Consent for publication}

Not applicable.

\section{Disclosure of potential conflicts of interest}

The authors indicated no potential conflicts of interest.

\section{References}

[1] J. Braun, J. Sieper, Ankylosing spondylitis, The Lancet, 369 (2007) 1379-1390.

[2] K. Le Blanc, D. Mougiakakos, Multipotent mesenchymal stromal cells and the innate immune system, Nature reviews. Immunology, 12 (2012) 383-396.

[3] S. Ghannam, J. Pene, G. Torcy-Moquet, C. Jorgensen, H. Yssel, Mesenchymal stem cells inhibit human Th17 cell differentiation and function and induce a T regulatory cell phenotype, Journal of immunology, 185 (2010) 302-312.

[4] V. Pistoia, L. Raffaghello, Mesenchymal stromal cells and autoimmunity, International immunology, 29 (2017) 49-58.

[5] Y. He, L.L. Xu, F.E. Feng, Q.M. Wang, X.L. Zhu, C.C. Wang, J.M. Zhang, H.X. Fu, L.P. Xu, K.Y. Liu, X.J. Huang, X.H. Zhang, Mesenchymal stem cell deficiency influences megakaryocytopoiesis through the TNFAIP3/NF-KB/SMAD pathway in patients with immune thrombocytopenia, Br J Haematol, 180 (2018) 395-411.

[6] L. Geng, X. Tang, K. Zhou, D. Wang, S. Wang, G. Yao, W. Chen, X. Gao, W. Chen, S. Shi, N. Shen, X. Feng, L. Sun, MicroRNA-663 induces immune dysregulation by inhibiting TGF- $\beta 1$ production in bone marrow-derived mesenchymal stem cells in patients with systemic lupus erythematosus, Cellular \& molecular immunology, 16 (2019) 260-274.

[7] Y. Wu, M. Ren, R. Yang, X. Liang, Y. Ma, Y. Tang, L. Huang, J. Ye, K. Chen, P. Wang, H. Shen, Reduced immunomodulation potential of bone marrow-derived mesenchymal stem cells induced CCR4+CCR6+ Th/Treg cell subset imbalance in ankylosing spondylitis, Arthritis research \& therapy, 13 (2011) R29.

[8] P. Wang, Y. Li, L. Huang, J. Yang, R. Yang, W. Deng, B. Liang, L. Dai, Q. Meng, L. Gao, X. Chen, J. Shen, Y. Tang, X. Zhang, J. Hou, J. Ye, K. Chen, Z. Cai, Y. Wu, H. Shen, Effects and safety of allogenic mesenchymal stem cell intravenous infusion in active ankylosing spondylitis patients who failed NSAIDs: a 20-week clinical trial, Cell transplantation, 23 (2014) 1293-1303.

[9] O. Delarosa, W. Dalemans, E. Lombardo, Toll-like receptors as modulators of mesenchymal stem cells, Frontiers in immunology, 3 (2012) 182.

[10] F. Liotta, R. Angeli, L. Cosmi, L. Fili, C. Manuelli, F. Frosali, B. Mazzinghi, L. Maggi, A. Pasini, V. Lisi, V. Santarlasci, L. Consoloni, M.L. Angelotti, P. Romagnani, P. Parronchi, M. Krampera, E. Maggi, S. Romagnani, F. Annunziato, Toll-like receptors 3 and 4 are expressed by human bone marrowderived mesenchymal stem cells and can inhibit their T-cell modulatory activity by impairing Notch signaling, Stem cells (Dayton, Ohio), 26 (2008) 279-289.

[11] R.S. Waterman, S.L. Tomchuck, S.L. Henkle, A.M. Betancourt, A new mesenchymal stem cell (MSC) paradigm: polarization into a proinflammatory MSC1 or an Immunosuppressive MSC2 phenotype, PloS one, 5 (2010) e10088.

[12] C.A. Opitz, U.M. Litzenburger, C. Lutz, T.V. Lanz, I. Tritschler, A. Koppel, E. Tolosa, M. Hoberg, J. Anderl, W.K. Aicher, M. Weller, W. Wick, M. Platten, Toll-like receptor engagement enhances the immunosuppressive properties of human bone marrow-derived mesenchymal stem cells by inducing indoleamine-2,3-dioxygenase-1 via interferon-beta and protein kinase R, Stem cells (Dayton, Ohio), 27 (2009) 909-919. 
[13] Y. Li, L. Huang, Z. Cai, W. Deng, P. Wang, H. Su, Y. Wu, H. Shen, A Study of the Immunoregulatory Function of TLR3 and TLR4 on Mesenchymal Stem Cells in Ankylosing Spondylitis, Stem Cells Dev, 28 (2019) 1398-1412.

[14] I. Ulitsky, D.P. Bartel, lincRNAs: genomics, evolution, and mechanisms, Cell, 154 (2013) 26-46.

[15] F. Kopp, J.T. Mendell, Functional Classification and Experimental Dissection of Long Noncoding RNAs, Cell, 172 (2018) $393-407$.

[16] P. Wang, Y. Xue, Y. Han, L. Lin, C. Wu, S. Xu, Z. Jiang, J. Xu, Q. Liu, X. Cao, The STAT3-binding long noncoding RNA Inc-DC controls human dendritic cell differentiation, Science, 344 (2014) 310-313.

[17] M. Du, L. Yuan, X. Tan, D. Huang, X. Wang, Z. Zheng, X. Mao, X. Li, L. Yang, K. Huang, F. Zhang, Y. Wang, X. Luo, D. Huang, K. Huang, The LPSinducible IncRNA Mirt2 is a negative regulator of inflammation, Nature communications, 8 (2017) 2049.

[18] P. Wang, Y. Li, L. Huang, J. Yang, R. Yang, W. Deng, B. Liang, L. Dai, Q. Meng, L. Gao, X. Chen, J. Shen, Y. Tang, X. Zhang, J. Hou, J. Ye, K. Chen, Z. Cai, Y. Wu, H. Shen, Effects and Safety of Allogenic Mesenchymal Stem Cells Intravenous Infusion in Active Ankylosing Spondylitis Patients Who Failed NSAIDs: A 20 Week Clinical Trial, Cell transplantation, (2013).

[19] S. Aggarwal, M.F. Pittenger, Human mesenchymal stem cells modulate allogeneic immune cell responses, Blood, 105 (2005) $1815-1822$.

[20] J. Galipeau, L. Sensébé, Mesenchymal Stromal Cells: Clinical Challenges and Therapeutic Opportunities, Cell stem cell, 22 (2018) $824-833$.

[21] S. Ma, N. Xie, W. Li, B. Yuan, Y. Shi, Y. Wang, Immunobiology of mesenchymal stem cells, Cell death and differentiation, 21 (2014) $216-225$.

[22] Y. Shi, Y. Wang, Q. Li, K. Liu, J. Hou, C. Shao, Y. Wang, Immunoregulatory mechanisms of mesenchymal stem and stromal cells in inflammatory diseases, Nature reviews. Nephrology, 14 (2018) 493-507.

[23] W. Zahari, S.N. Hashim, M.F. Yusof, Z.F. Osman, T.P. Kannan, K.I. Mokhtar, A. Ahmad, K.B. Noordin, Immunomodulatory Effect of Cytokines in the Differentiation of Mesenchymal Stem Cells: A Review, Current stem cell research \& therapy, 12 (2017) 197-206.

[24] M.E. Castro-Manrreza, J.J. Montesinos, Immunoregulation by mesenchymal stem cells: biological aspects and clinical applications, Journal of immunology research, 2015 (2015) 394917.

[25] F.K. Tan, K. Farheen, The potential importance of Toll-like receptors in ankylosing spondylitis, International journal of clinical rheumatology, 6 (2011) 649-654.

[26] Y. Li, L. Huang, Z. Cai, W. Deng, P. Wang, H. Su, Y. Wu, H. Shen, A Study of the Immunoregulatory Function of TLR3 and TLR4 on Mesenchymal Stem Cells in Ankylosing Spondylitis, Stem cells and development, 28 (2019) 1398-1412.

[27] T. Kawasaki, T. Kawai, Toll-like receptor signaling pathways, Frontiers in immunology, 5 (2014) 461.

[28] B. Prajapati, P.K. Jena, P. Rajput, K. Purandhar, S. Seshadri, Understanding and modulating the Toll like Receptors (TLRs) and NOD like Receptors (NLRs) cross talk in type 2 diabetes, Current diabetes reviews, 10 (2014) 190-200.

[29] A. Gardini, R. Shiekhattar, The many faces of long noncoding RNAs, The FEBS journal, 282 (2015) 1647-1657.

[30] X. Li, W. Chai, G. Zhang, M. Ni, J. Chen, J. Dong, Y. Zhou, L. Hao, Y. Bai, Y. Wang, Down-Regulation of IncRNA-AK001085 and its Influences on the Diagnosis of Ankylosing Spondylitis, Medical science monitor : international medical journal of experimental and clinical research, 23 (2017) 11-16.

[31] Z. Xie, J. Li, P. Wang, Y. Li, X. Wu, S. Wang, H. Su, W. Deng, Z. Liu, S. Cen, Y. Ouyang, Y. Wu, H. Shen, Differential Expression Profiles of Long Noncoding RNA and mRNA of Osteogenically Differentiated Mesenchymal Stem Cells in Ankylosing Spondylitis, J Rheumatol, 43 (2016) $1523-1531$.

[32] J. Sui, Y. Miao, J. Han, H. Nan, B. Shen, X. Zhang, Y. Zhang, Y. Wu, W. Wu, T. Liu, S. Xu, S. Yang, L. Yin, Y. Pu, G. Liang, Systematic analyses of a novel IncRNA-associated signature as the prognostic biomarker for Hepatocellular Carcinoma, Cancer medicine, 7 (2018) $3240-3256$.

[33] M.R. Hadjicharalambous, B.T. Roux, C.A. Feghali-Bostwick, L.A. Murray, D.L. Clarke, M.A. Lindsay, Long Non-coding RNAs Are Central Regulators of the IL-1ß-Induced Inflammatory Response in Normal and Idiopathic Pulmonary Lung Fibroblasts, Frontiers in immunology, 9 (2018) 2906.

[34] M. Sun, W.L. Kraus, From discovery to function: the expanding roles of long noncoding RNAs in physiology and disease, Endocrine reviews, 36 (2015) 25-64.

[35] X. Shi, Y. Bai, G. Zhang, Y. Liu, H. Xiao, X. Liu, W. Zhang, Effects of over-expression of SOD2 in bone marrow-derived mesenchymal stem cells on traumatic brain injury, Cell and tissue research, 372 (2018) 67-75. 
[36] G. Fonteneau, C. Bony, R. Goulabchand, A.T.J. Maria, A. Le Quellec, S. Rivière, C. Jorgensen, P. Guilpain, D. Noël, Serum-Mediated Oxidative Stress from Systemic Sclerosis Patients Affects Mesenchymal Stem Cell Function, Frontiers in immunology, 8 (2017) 988.

\section{Tables}

Table 1: The characteristics of mRNAs with the largest fold change.

\begin{tabular}{llll}
\hline Gene name & Accession no. & Log2 Fold change & Regulation \\
\hline CXCL10 & NM_001565.3 & 12.58 & up \\
CXCL11 & NM_005409.4 & 10.14 & up \\
RSAD2 & NM_080657.4 & 8.27 & up \\
IDO1 & NM_002164.5 & 7.98 & up \\
CXCL8 & NM_000584.3 & 7.95 & up \\
CXCL1 & NR_046035.1 & 7.86 & up \\
IFIT1 & NM_001270930.1 & 7.30 & up \\
OASL & NM_003733.3 & 6.95 & up \\
CCL20 & NM_004591.2 & 6.86 & up \\
CXCL3 & NM_002090.2 & 6.79 & up \\
CCL5 & NM_001278736.1 & 6.56 & up \\
IFIT3 & NM_001289758.1 & 6.54 & up \\
CMPK2 & NM_207315.3 & 6.39 & up \\
CD274 & NM_001267706.1 & 6.19 & up \\
OASL & NM_198213.2 & 6.08 & up \\
PTGS2 & NM_000963.3 & 6.04 & up \\
IL6 & NM_001318095.1 & 5.81 & up \\
SOD2 & NM_001322816.1 & 5.79 & up \\
CXCL8 & NM_001354840.1 & 5.56 & up \\
GBP5 & NM_052942.3 & 5.47 & up \\
\hline & & & \\
\hline
\end{tabular}

Table 2: The characteristics of LncRNAs with the largest fold change.

\begin{tabular}{|c|c|c|c|c|c|c|c|c|c|}
\hline Gene Symbol & Accession No. & $\begin{array}{c}\text { Fold } \\
\text { change }\end{array}$ & Regulation & Chromosome & Strand & Start & End & Feature & Size(bp) \\
\hline GBP1P1 & NR_003133.2 & 65.35 & up & 1 & + & 89407679 & 89424934 & miscRNA & 1234 \\
\hline LOC105370436 & XR_943719.2 & 35.08 & up & 14 & + & 31271945 & 31276870 & ncRNA & 626 \\
\hline LOC105376014 & XR_929550.3 & 18.12 & up & 9 & - & 32450235 & 32454362 & ncRNA & 2133 \\
\hline MIR3142HG & NR_132748.1 & 14.70 & up & 5 & + & 160468251 & 160487426 & ncRNA & 2318 \\
\hline LOC105371619 & XR_922291.3 & 14.43 & up & 1 & + & 173637658 & 173681709 & ncRNA & 582 \\
\hline LOC105369543 & XR_948124.3 & 14.25 & up & 11 & + & 123651728 & 123672257 & ncRNA & 3095 \\
\hline LOC105374444 & XR_925284.2 & 11.54 & up & 4 & + & 47627252 & 47636569 & ncRNA & 1416 \\
\hline ANO7L1 & XR_946991.2 & 11.17 & up & 1 & - & 16215438 & 16217420 & miscRNA & 1466 \\
\hline PACERR & NR_125801.1 & 9.48 & up & 1 & + & 186680654 & 186681446 & ncRNA & 793 \\
\hline LOC105375914 & XR_001745967.1 & 9.23 & up & 8 & + & 78804578 & 78937632 & ncRNA & 3370 \\
\hline
\end{tabular}

Supplementary Table 1: GO analysis of DE mRNA. 


\begin{tabular}{|c|c|c|c|c|c|}
\hline ID & Term & Category & Count & $\begin{array}{l}\text { Fold } \\
\text { Enrichment }\end{array}$ & $P$ value \\
\hline GO:0051607 & defense response to virus & $\begin{array}{l}\text { Biological } \\
\text { process }\end{array}$ & 47 & 10.03 & $\begin{array}{l}4.03 \mathrm{E}- \\
34\end{array}$ \\
\hline GO:0060337 & type I interferon signaling pathway & $\begin{array}{l}\text { Biological } \\
\text { process }\end{array}$ & 26 & 13.95 & $\begin{array}{l}1.30 \mathrm{E}- \\
23\end{array}$ \\
\hline GO:0060333 & interferon-gamma-mediated signaling pathway & $\begin{array}{l}\text { Biological } \\
\text { process }\end{array}$ & 26 & 12.58 & $\begin{array}{l}3.15 \mathrm{E}- \\
22\end{array}$ \\
\hline GO:0006954 & inflammatory response & $\begin{array}{l}\text { Biological } \\
\text { process }\end{array}$ & 52 & 4.81 & $\begin{array}{l}2.45 \mathrm{E}- \\
21\end{array}$ \\
\hline GO:0009615 & response to virus & $\begin{array}{l}\text { Biological } \\
\text { process }\end{array}$ & 26 & 8.35 & $\begin{array}{l}3.55 \mathrm{E}- \\
17\end{array}$ \\
\hline GO:0045071 & negative regulation of viral genome replication & $\begin{array}{l}\text { Biological } \\
\text { process }\end{array}$ & 16 & 14.09 & $\begin{array}{l}4.25 \mathrm{E}- \\
15\end{array}$ \\
\hline GO:0051092 & $\begin{array}{l}\text { positive regulation of NF-kappaB transcription factor } \\
\text { activity }\end{array}$ & $\begin{array}{l}\text { Biological } \\
\text { process }\end{array}$ & 26 & 6.77 & $\begin{array}{l}8.34 \mathrm{E}- \\
15\end{array}$ \\
\hline GO:0006955 & immune response & $\begin{array}{l}\text { Biological } \\
\text { process }\end{array}$ & 37 & 3.73 & $\begin{array}{l}5.49 \mathrm{E}- \\
12\end{array}$ \\
\hline GO:0032496 & response to lipopolysaccharide & $\begin{array}{l}\text { Biological } \\
\text { process }\end{array}$ & 24 & 5.12 & $\begin{array}{l}4.75 \mathrm{E}- \\
11\end{array}$ \\
\hline GO:0070098 & chemokine-mediated signaling pathway & $\begin{array}{l}\text { Biological } \\
\text { process }\end{array}$ & 16 & 7.97 & $\begin{array}{l}9.63 \mathrm{E}- \\
11\end{array}$ \\
\hline GO:0008009 & chemokine activity & $\begin{array}{l}\text { Molecular } \\
\text { function }\end{array}$ & 16 & 11.24 & $\begin{array}{l}2.64 \mathrm{E}- \\
13\end{array}$ \\
\hline GO:0045236 & CXCR chemokine receptor binding & $\begin{array}{l}\text { Molecular } \\
\text { function }\end{array}$ & 5 & 18.73 & $\begin{array}{l}2.57 \mathrm{E}- \\
06\end{array}$ \\
\hline GO:0004842 & ubiquitin-protein transferase activity & $\begin{array}{l}\text { Molecular } \\
\text { function }\end{array}$ & 26 & 2.74 & $\begin{array}{l}3.57 \mathrm{E}- \\
06\end{array}$ \\
\hline GO:0003725 & double-stranded RNA binding & $\begin{array}{l}\text { Molecular } \\
\text { function }\end{array}$ & 10 & 5.72 & $\begin{array}{l}8.18 \mathrm{E}- \\
06\end{array}$ \\
\hline GO:0003700 & $\begin{array}{l}\text { transcription factor activity, sequence-specific DNA } \\
\text { binding }\end{array}$ & $\begin{array}{l}\text { Molecular } \\
\text { function }\end{array}$ & 47 & 1.85 & $\begin{array}{l}3.69 \mathrm{E}- \\
05\end{array}$ \\
\hline GO:0016874 & ligase activity & $\begin{array}{l}\text { Molecular } \\
\text { function }\end{array}$ & 19 & 2.81 & $\begin{array}{l}5.17 \mathrm{E}- \\
05\end{array}$ \\
\hline GO:0005125 & cytokine activity & $\begin{array}{l}\text { Molecular } \\
\text { function }\end{array}$ & 16 & 3.10 & $\begin{array}{l}6.26 \mathrm{E}- \\
05\end{array}$ \\
\hline GO:0004871 & signal transducer activity & $\begin{array}{l}\text { Molecular } \\
\text { function }\end{array}$ & 17 & 2.95 & $\begin{array}{l}6.83 \mathrm{E}- \\
05\end{array}$ \\
\hline GO:0008270 & zinc ion binding & $\begin{array}{l}\text { Molecular } \\
\text { function }\end{array}$ & 57 & 1.69 & $\begin{array}{l}7.09 \mathrm{E}- \\
05\end{array}$ \\
\hline GO:0003950 & NAD+ ADP-ribosyltransferase activity & $\begin{array}{l}\text { Molecular } \\
\text { function }\end{array}$ & 6 & 7.49 & $\begin{array}{l}1.15 \mathrm{E}- \\
04\end{array}$ \\
\hline GO:0005737 & cytoplasm & $\begin{array}{l}\text { Cellular } \\
\text { component }\end{array}$ & 189 & 1.37 & $\begin{array}{l}2.51 \mathrm{E}- \\
07\end{array}$ \\
\hline GO:0005829 & cytosol & $\begin{array}{l}\text { Cellular } \\
\text { component }\end{array}$ & 136 & 1.50 & $\begin{array}{l}2.92 \mathrm{E}- \\
07\end{array}$ \\
\hline GO:0005615 & extracellular space & $\begin{array}{l}\text { Cellular } \\
\text { component }\end{array}$ & 65 & 1.79 & $\begin{array}{l}2.98 \mathrm{E}- \\
06\end{array}$ \\
\hline GO:0005634 & nucleus & $\begin{array}{l}\text { Cellular } \\
\text { component }\end{array}$ & 186 & 1.30 & $\begin{array}{l}1.38 \mathrm{E}- \\
05\end{array}$ \\
\hline GO:0005576 & extracellular region & $\begin{array}{l}\text { Cellular } \\
\text { component }\end{array}$ & 66 & 1.61 & $\begin{array}{l}7.97 \mathrm{E}- \\
05\end{array}$ \\
\hline GO:0043657 & host cell & $\begin{array}{l}\text { Cellular } \\
\text { component }\end{array}$ & 3 & 21.58 & $\begin{array}{l}2.05 \mathrm{E}- \\
04\end{array}$ \\
\hline GO:0033256 & I-kappaB/NF-kappaB complex & $\begin{array}{l}\text { Cellular } \\
\text { component }\end{array}$ & 3 & 21.58 & $\begin{array}{l}2.05 \mathrm{E}- \\
04\end{array}$ \\
\hline
\end{tabular}


GO:0031264 death-inducing signaling complex

Supplementary Table 2: Pathways with the largest significant difference of mRNA in KEGG analysis.

\begin{tabular}{|c|c|c|c|c|c|}
\hline ID & Pathway & Count & $\begin{array}{l}\text { Fold } \\
\text { Enrichment }\end{array}$ & $\begin{array}{l}\mathrm{P} \\
\text { value }\end{array}$ & Gene \\
\hline hsa04621 & $\begin{array}{l}\text { NOD-like } \\
\text { receptor } \\
\text { signaling } \\
\text { pathway }\end{array}$ & 38 & 6.67 & $\begin{array}{l}1.39 \mathrm{E}- \\
21\end{array}$ & $\begin{array}{l}\text { CXCL8; GBP3; NAMPT; RBCK1; CXCL2; GBP4; OAS1; MAPK8; GBP2; } \\
\text { GBP1; TICAM1; AIM2; GBP5; IFNAR2; TNFAIP3; BIRC3; IL1B; CXCL1; } \\
\text { RIPK2; BIRC2; IRF9; MYD88; NLRP3; OAS2; IL6; RIPK1; NFKB1; } \\
\text { PANX1; CCL2; CCL5; IFNB1; CXCL3; ANTXR2; STAT2; STAT1; CASP1; } \\
\text { NOD1; OAS3 }\end{array}$ \\
\hline hsa04668 & $\begin{array}{l}\text { TNF } \\
\text { signaling } \\
\text { pathway }\end{array}$ & 31 & 8.47 & $\begin{array}{l}4.75 \mathrm{E}- \\
21\end{array}$ & $\begin{array}{l}\text { CXCL2; FAS; ICAM1; CSF1; VCAM1; CASP7; PTGS2; MAP3K5; MAPK8; } \\
\text { TNFAIP3; BIRC3; IL1B; CXCL1; BIRC2; IL18R1; MLKL; CCL20; LIF; } \\
\text { MAP3K8; CX3CL1; IL6; RIPK1; MMP3; NFKB1; CCL2; CCL5; CXCL5; } \\
\text { CXCL3; CXCL10; CFLAR; TRAF1 }\end{array}$ \\
\hline hsa05164 & Influenza A & 35 & 5.97 & $\begin{array}{l}2.95 \mathrm{E}- \\
18\end{array}$ & $\begin{array}{l}\text { CXCL8; FAS; ICAM1; TLR3; RSAD2; OAS1; TNFSF10; CIITA; MAPK8; } \\
\text { HLA-DOB; TRIM25; MX1; TICAM1; IFNAR2; PML; DDX58; IL1B; } \\
\text { EIF2AK2; IRF9; MYD88; NLRP3; OAS2; IL6; NFKB1; CCL2; CCL5; } \\
\text { JAK2; IFNB1; CXCL10; IFNGR2; STAT2; CASP1; STAT1; OAS3; IFIH1 }\end{array}$ \\
\hline hsa05168 & $\begin{array}{l}\text { Herpes } \\
\text { simplex } \\
\text { infection }\end{array}$ & 34 & 5.42 & $\begin{array}{l}2.12 \mathrm{E}- \\
16\end{array}$ & $\begin{array}{l}\text { HLA-F; FAS; SP100; TLR3; OAS1; MAPK8; HLA-DOB; CD74; TICAM1; } \\
\text { IFNAR2; PML; TNFSF14; DDX58; IL1B; EIF2AK2; IRF9; MYD88; } \\
\text { TRAF1; IFIT1; OAS2; NFKB1; IL6; CCL2; CCL5; JAK2; IFNB1; TAP1; } \\
\text { TAP2; IFNGR2; STAT2; C3; STAT1; OAS3; IFIH1 }\end{array}$ \\
\hline hsa04064 & $\begin{array}{l}\text { NF-kappa B } \\
\text { signaling } \\
\text { pathway }\end{array}$ & 22 & 6.83 & $\begin{array}{l}4.16 \mathrm{E}- \\
13\end{array}$ & $\begin{array}{l}\text { CXCL8; CXCL2; ICAM1; VCAM1; PTGS2; TRIM25; TICAM1; TNFAIP3; } \\
\text { TNFSF14; BIRC3; DDX58; IL1B; BIRC2; RELB; MYD88; RIPK1; NFKB1; } \\
\text { BCL2A1; CCL4; NFKB2; CFLAR; TRAF1 }\end{array}$ \\
\hline hsa04060 & $\begin{array}{l}\text { Cytokine- } \\
\text { cytokine } \\
\text { receptor } \\
\text { interaction }\end{array}$ & 36 & 3.93 & $\begin{array}{l}8.02 \mathrm{E}- \\
13\end{array}$ & $\begin{array}{l}\text { CXCL8; IL6R; FLT3; CXCL9; CXCL2; FAS; CSF1; IL15RA; TNFSF10; } \\
\text { CXCL11; TNFSF9; IL1RAP; BMP2; IFNAR2; TNFSF14; IL1B; CXCL1; } \\
\text { IL18R1; CCL7; CCL20; LIF; CXCL16; CXCL6; CX3CL1; IL6; IL7; CCL2; } \\
\text { CCL5; IFNB1; TSLP; CXCL3; CXCL5; CXCL10; CCL4; IFNGR2; PDGFC }\end{array}$ \\
\hline hsa04217 & Necroptosis & 27 & 4.86 & $\begin{array}{l}5.04 \mathrm{E}- \\
12\end{array}$ & $\begin{array}{l}\text { RBCK1; FAS; STAT4; TLR3; PLA2G4A; TNFSF10; MAPK8; TICAM1; } \\
\text { IFNAR2; TNFAIP3; BIRC3; IL1B; EIF2AK2; MLKL; BIRC2; IRF9; } \\
\text { NLRP3; PARP4; RIPK1; JAK2; IFNB1; IFNGR2; STAT5A; STAT2; } \\
\text { CASP1; STAT1; CFLAR }\end{array}$ \\
\hline hsa04657 & $\begin{array}{l}\text { IL-17 } \\
\text { signaling } \\
\text { pathway }\end{array}$ & 19 & 6.03 & $\begin{array}{l}1.83 \mathrm{E}- \\
10\end{array}$ & $\begin{array}{l}\text { CXCL8; CXCL2; PTGS2; MMP13; MAPK8; TNFAIP3; IL1B; CXCL1; } \\
\text { CCL7; CCL20; CXCL6; TRAF3IP2; IL6; NFKB1; MMP3; CCL2; CXCL5; } \\
\text { CXCL3; CXCL10 }\end{array}$ \\
\hline hsa05162 & Measles & 22 & 4.84 & $\begin{array}{l}5.58 \mathrm{E}- \\
10\end{array}$ & $\begin{array}{l}\text { FAS; OAS1; TNFSF10; MX1; IFNAR2; TNFAIP3; DDX58; IL1B; } \\
\text { EIF2AK2; IRF9; MYD88; OAS2; IL6; NFKB1; JAK2; IFNB1; IFNGR2; } \\
\text { STAT5A; STAT2; STAT1; OAS3; IFIH1 }\end{array}$ \\
\hline hsa04620 & $\begin{array}{l}\text { Toll-like } \\
\text { receptor } \\
\text { signaling } \\
\text { pathway }\end{array}$ & 18 & 5.11 & $\begin{array}{l}9.27 \mathrm{E}- \\
09\end{array}$ & $\begin{array}{l}\text { CXCL8; TICAM1; MAP3K8; IL6; RIPK1; NFKB1; IFNAR2; CXCL11; } \\
\text { CCL5; IFNB1; MAPK8; IL1B; CXCL9; CXCL10; CCL4; STAT1; MYD88; } \\
\text { TLR3 }\end{array}$ \\
\hline
\end{tabular}

Supplementary Table 3: Primers of the analyzed genes. 


\begin{tabular}{|c|c|c|}
\hline Gene Name & Forward Primer & Reverse Primer \\
\hline GAPDH & AAGGTGAAGGTCGGAGTCAA & AATGAAGGGGTCATTGATGG \\
\hline MIR3142HG & TGGCTCAGAACTCCGATT & ССТАСТССТСАСАGATACAC \\
\hline LOC105374444 & AGCCCTCTTTGGTCAACTCC & TGGTTGCAGCATTGTCTTGG \\
\hline LOC105371619 & ATGTCTGTAGCATGCGGCTT & TTTCAGAAAACAGGCCCCG \\
\hline PACERR & CCGTGTCTGGTCTGTACGTC & AACCTTACTCGCCCCAGTCT \\
\hline LOC105375914 & ACGCAAGCTGGGTTATTGGA & AGCAACTGTGGTTGTCAGAT \\
\hline CXCL1 & СТСTTCTTCCCTAGGAGCGTC & GATGCAGGATTGAGGCAAGC \\
\hline CXCL8 & ACTGAGAGTGATTGAGAGTGGAC & AACССTCTGCACCCAGTTTTC \\
\hline CXCL10 & GTGGCATTCAAGGAGTACCTC & TGATGGCCTTCGATTCTGGATT \\
\hline CXCL11 & GACGCTGTCTTTGCATAGGC & GGATTTAGGCATCGTTGTCCTTT \\
\hline CCL20 & TGCTGTACCAAGAGTTTGCTC & CGCACACAGACAACTTTTTCTTT \\
\hline TNF- $\alpha$ & ССТСТСТСТАATCAGСССТСТG & GAGGACCTGGGAGTAGATGAG \\
\hline CXCL9 & TGAGAAAGGGTCGCTGTTCC & GGGCTTGGGGCAAATTGTTT \\
\hline PDL1 & GCTGCACTAATTGTCTATTGGGA & AATTCGCTTGTAGTCGGCACC \\
\hline IL-1 $\beta$ & ATGATGGCTTATTACAGTGGCAA & GTCGGAGATTCGTAGCTGGA \\
\hline IL-6 & АCTCACCTCTTCAGAACGAATTG & CCATCTTTGGAAGGTTCAGGTTG \\
\hline INOS & TTCAGTATCACAACCTCAGCAAG & TGGACCTGCAAGTTAAAATCCC \\
\hline
\end{tabular}

\section{Figures}



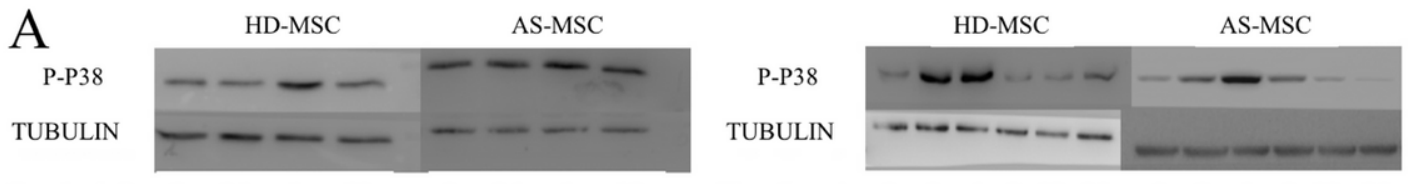

$\begin{array}{llllllllll}\text { Con. }(\mu \mathrm{g} / \mathrm{ml}) & 0 & 0.1 & 1 & 10 & 0 & 0.1 & 1 & 10 \\ & & & & & & \end{array}$

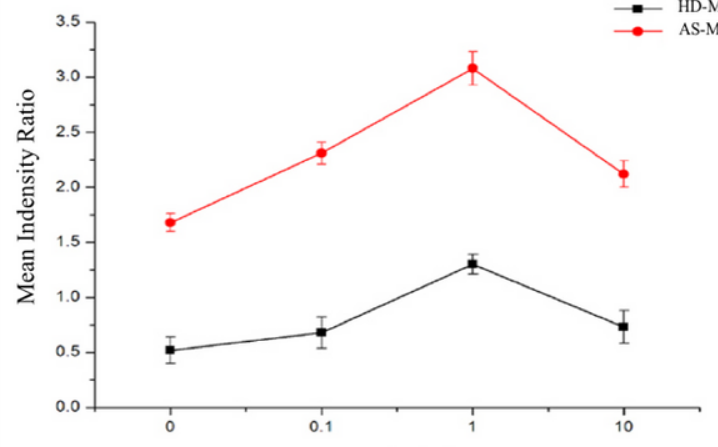

Time (hours) $\quad 0 \begin{array}{lllllllllllll}0 & 2 & 4 & 8 & 12 & 24 & 0 & 2 & 4 & 8 & 12 & 24\end{array}$

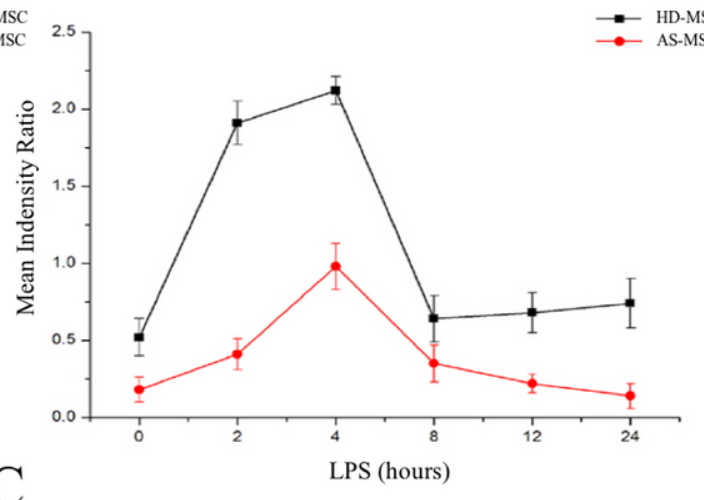

B

LPS $(\mu \mathrm{g} / \mathrm{ml})$
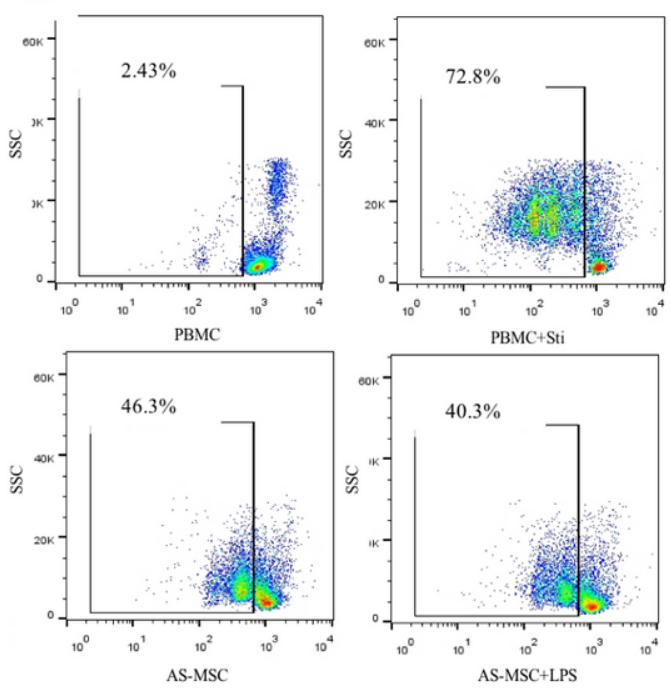

$\mathrm{C}$

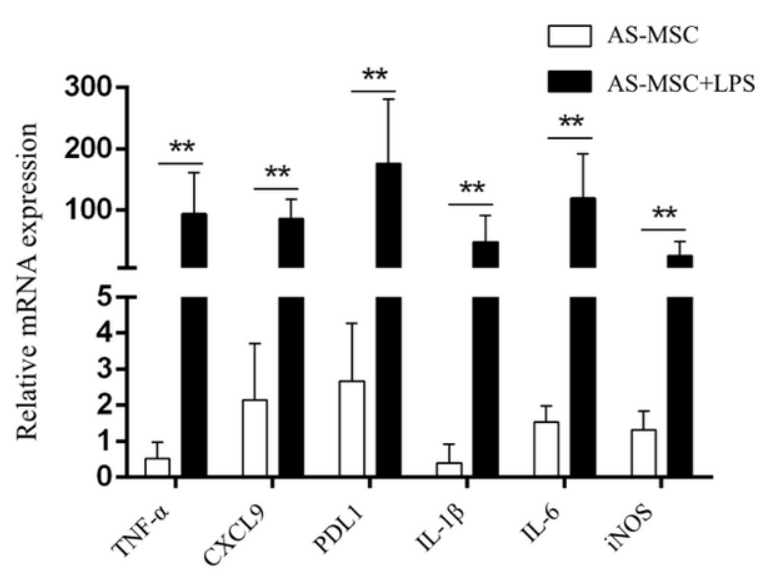

Figure 1

The immunoregulatory function of TLR4-primed AS-MSCs. A: To determine the best duration and concentration of TLR4 ligand pre-stimulation, we examined the level of $\mathrm{p} 38$ phosphorylation by western blotting. MSCs were exposed to LPS at four different concentrations $(0 \mu \mathrm{g} / \mathrm{ml}, 0.1 \mu \mathrm{g} / \mathrm{ml}, 1$ $\mu \mathrm{g} / \mathrm{ml}$, and $10 \mu \mathrm{g} / \mathrm{ml}$ ) for 4 hours or treated at the concentration of $1 \mu \mathrm{g} / \mathrm{ml}$ for the indicated time (0 hours, 2 hours, 4 hours, 8 hours, 12 hours or 24 hours). The upregulation of the phospho-p38 level was highest at 4 hours with the concentration of $1 \mu \mathrm{g} / \mathrm{ml}$ LPS and declined thereafter. B: ASMSCs were pre-stimulated with or without $1 \mu \mathrm{g} / \mathrm{ml}$ LPS for 4 hours and then co-cultured with PBMCs at a ratio of 1:10 (MSCs: PBMCs) for 5 days. All PBMCs were then collected for assessment by flow cytometry to determine the positive percentage of CFSE-diluted cells (gated) to evaluate proliferation. AS-MSCs inhibited the proliferation of PBMCs, and this effect was strengthened by the activation of TLR4. C: The gene expression of cytokines and chemokines in AS-MSCs after LPS stimulation was detected by qRT-PCR. The symbol “*” represents $\mathrm{P}<0.05$. 

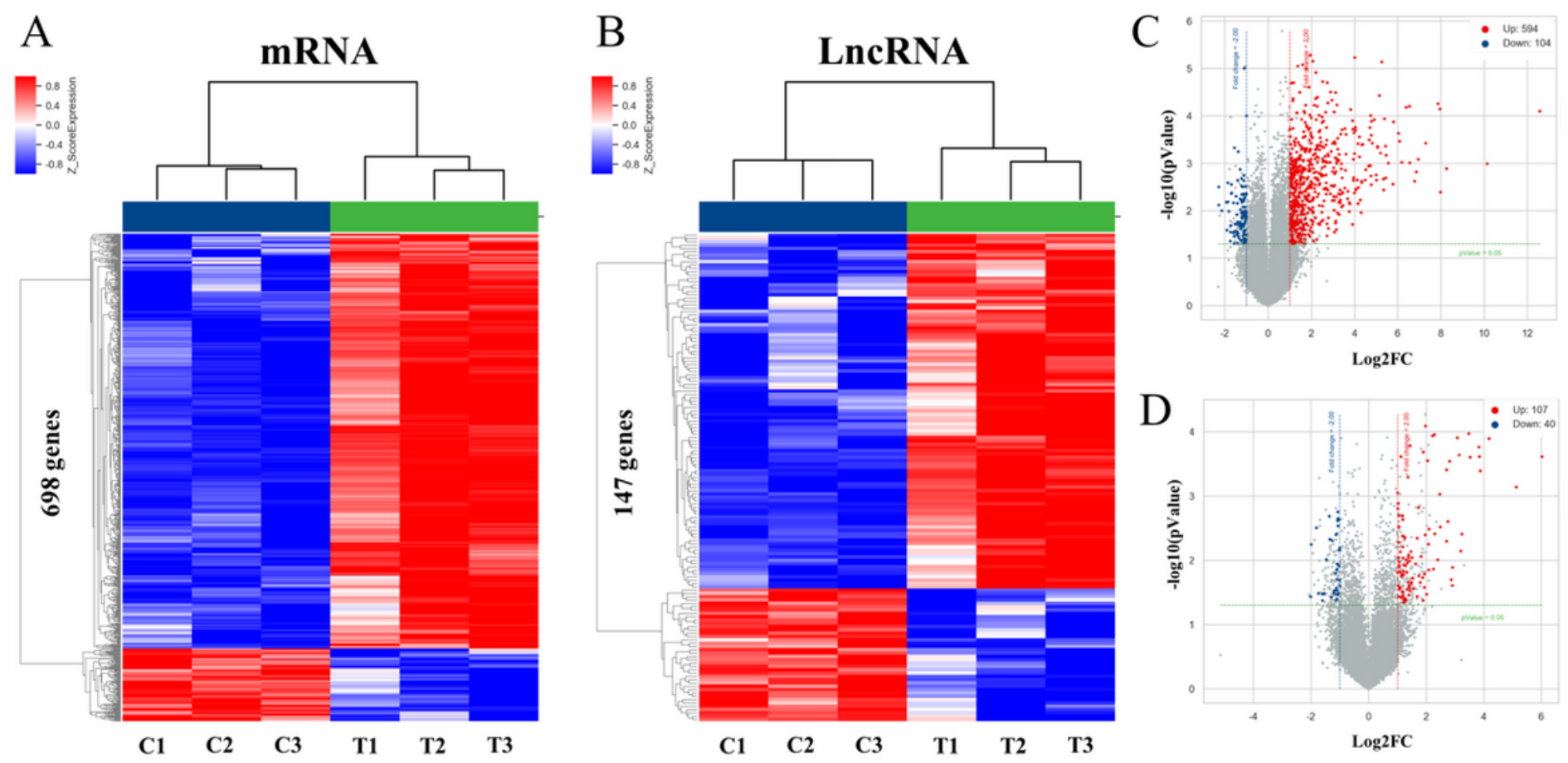

Figure 2

Identification of DE IncRNAs and mRNAs. A: Heatmaps of DE mRNAs between TLR4-primed AS-MSCs and unstimulated AS-MSCs. B: Heatmaps of DE IncRNAs between TLR4-primed AS-MSCs and unstimulated AS-MSCs. C: Volcano plots of DE mRNAs between TLR4-primed AS-MSCs and unstimulated AS-MSCs. D: Volcano plots of DE IncRNAs between TLR4-primed AS-MSCs and unstimulated AS-MSCs.

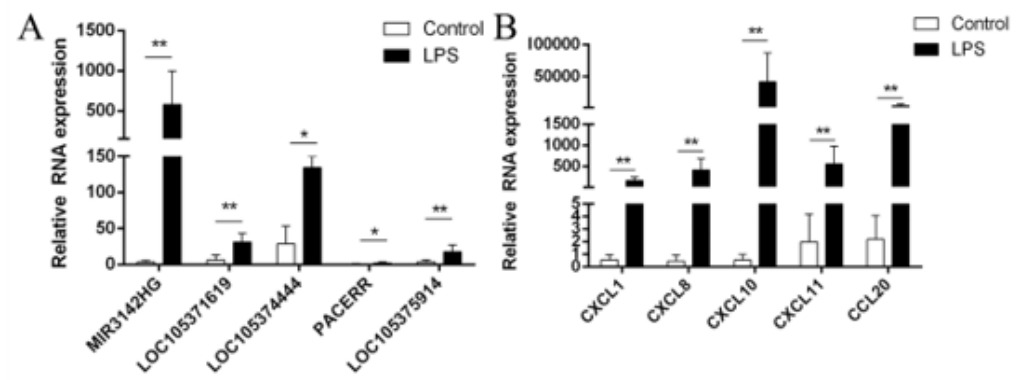

Figure 3

Validation of DE mRNAs and IncRNAs. A: DE IncRNAs were confirmed by qRT-PCR. B: DE mRNAs were confirmed by qRT-PCR. 


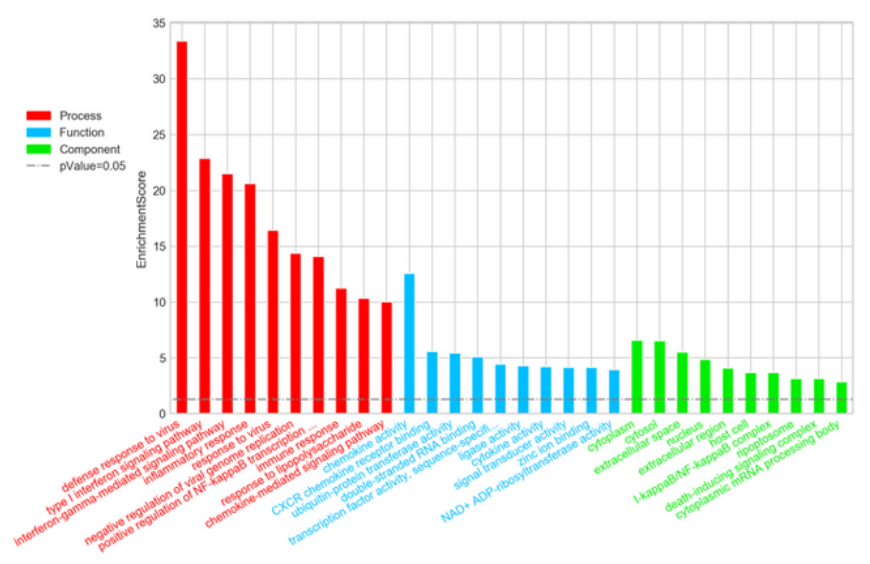

C

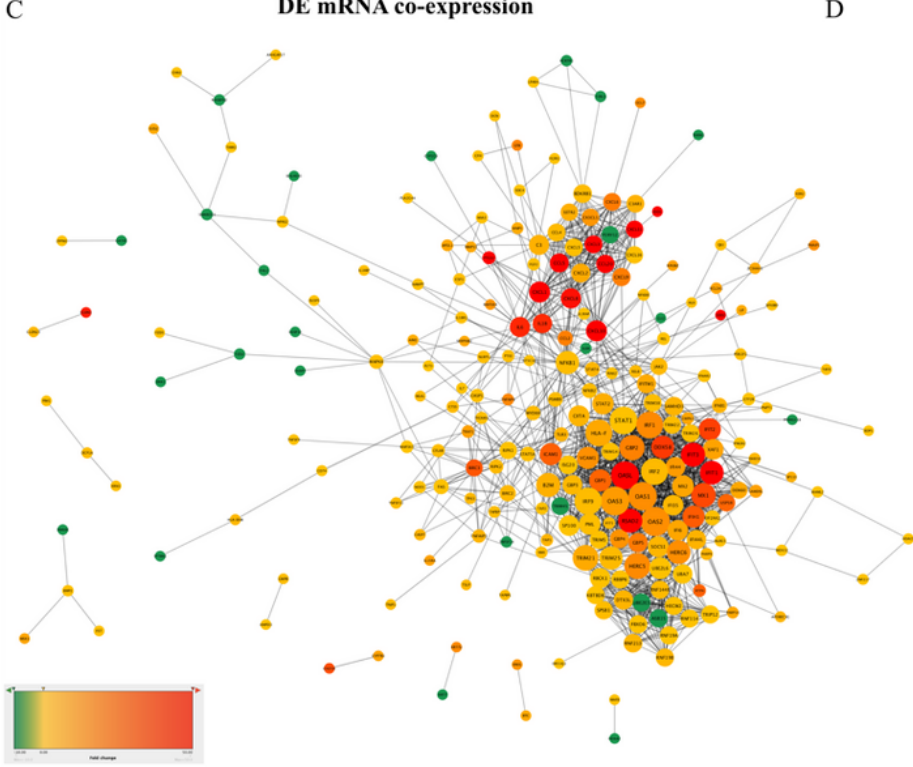

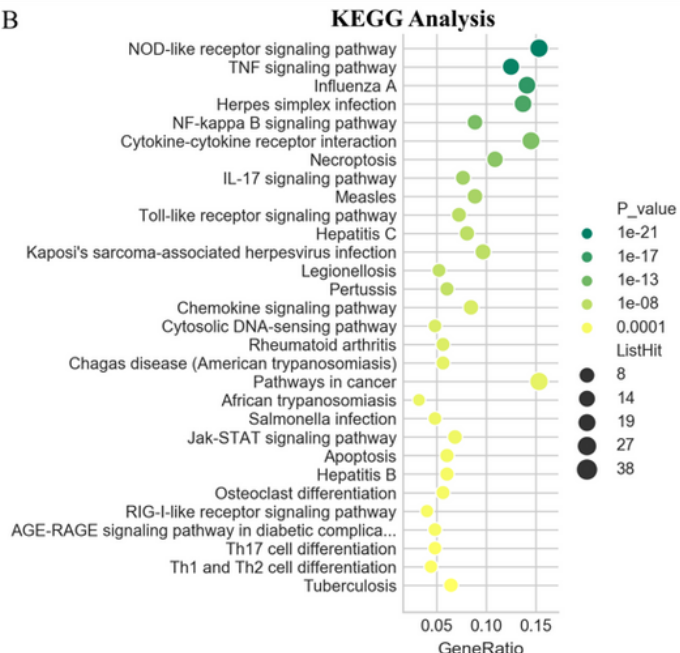

DE IncRNA and mRNA co-expression

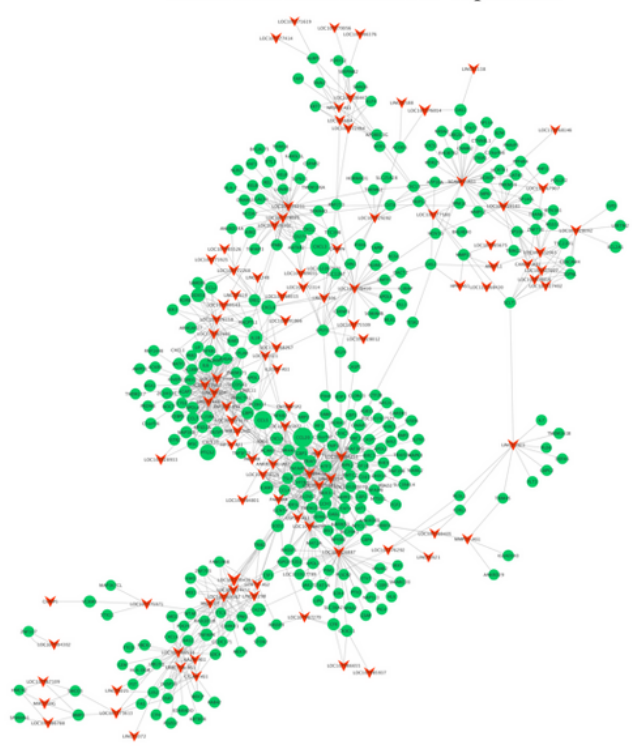

Figure 4

Advanced analyses of DE IncRNAs and mRNAs. A: The top 10 terms identified by GO analysis of molecular functions, biological processes and cellular components are shown. B: DE mRNAs were clustered by KEGG analysis, and the top 30 pathways are shown. C: Interactions among mRNAs. D: Co-expression network of DE IncRNAs and DE mRNAs.

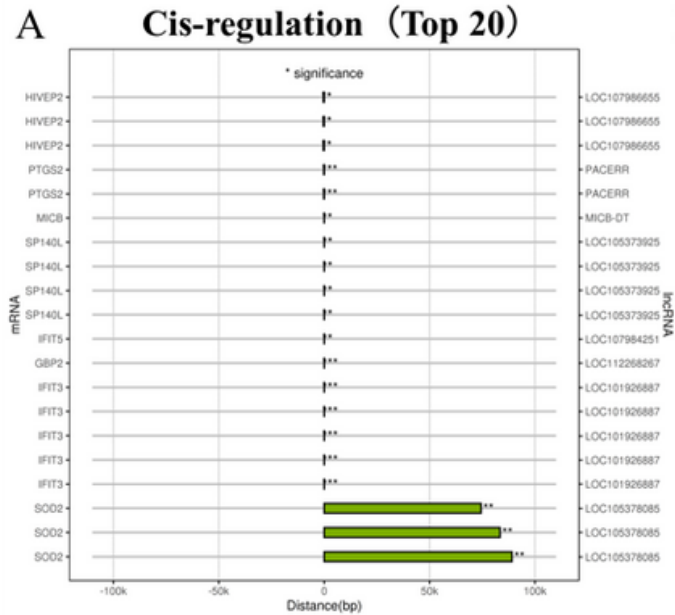

B Trans-regulation (Top 500)

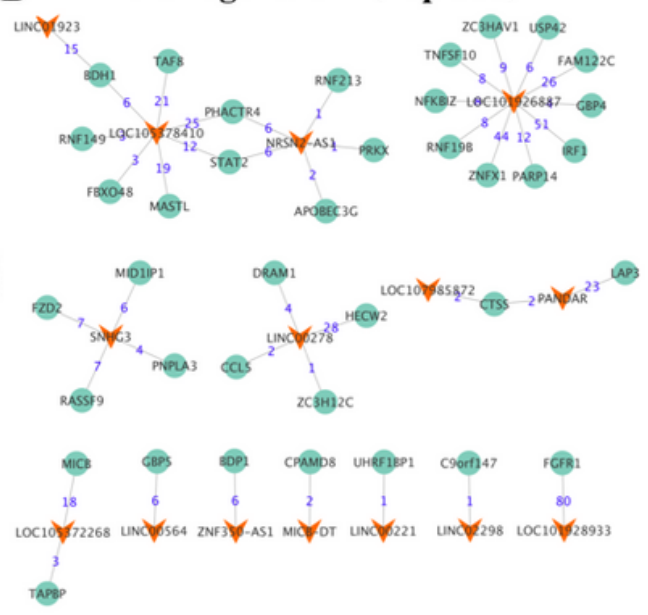

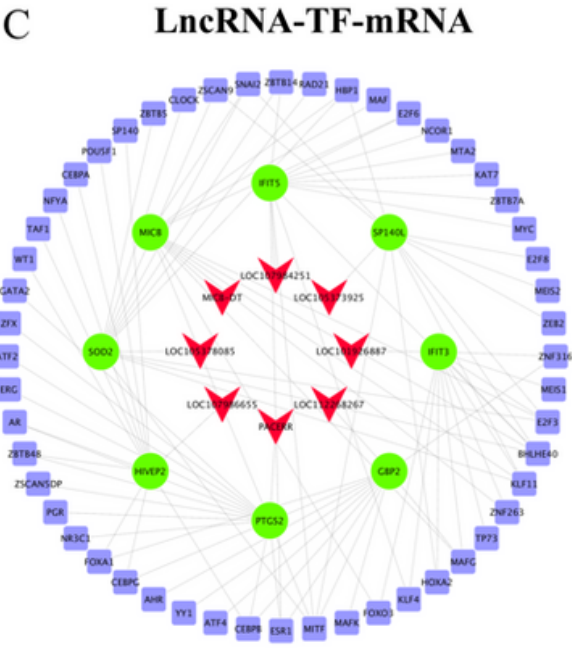

Figure 5 
LncRNA-TF-mRNA network. A: Top 20 terms for cis-regulation prediction. B: Predicted trans-regulation of DE IncRNAs and mRNAs. C: LncRNA-TFmRNA network. 